\title{
Kemampuan Berpikir Kritis Peserta Didik dalam Memecahkan Masalah Matematik Berdasarkan Gaya Belajar
}

\author{
Vepi Apiati ${ }^{*}$ dan Redi Hermanto ${ }^{2}$ \\ $1^{*}, 2 J u r u s a n$ Pendidikan Matematika, Universitas Siliwangi \\ Jalan Siliwangi No. 24, Tasikmalaya, Jawa Barat, Indonesia \\ 1*vepiapiati@unsil.ac.id; ${ }^{2}$ redihermanto@unsil.ac.id
}

Artikel diterima: 24-11-2019, direvisi: 28-01-2020, diterbitkan: 31-01-2020

\begin{abstract}
Abstrak
Berpikir kritis merupakan keterampilan atau strategi kognitif dalam menentukan tujuan. Setiap peserta didik memiliki gaya belajar yang berbeda-beda. Tujuan dari penelitian ini adalah untuk mendeskripsikan kemampuan berpikir kritis peserta didik dalam memecahkan masalah matematik berdasarkan gaya belajar David Kolb. Pendekatan dalam penelitian ini menggunakan pendekatan kualitatif. Pemilihan subjek dalam penelitian ini berdasarkan purposive sampling, dengan mempertimbangkan peserta didik yang mampu mengerjakan tes dengan memenuhi semua indikator kemampuan berpikir kritis matematis untuk mewakili setiap tipe gaya belajar David Kolb. Teknis analisis data yang digunakan meliputi reduksi data, penyajian data, dan verifikasi data. Hasil penelitian diperoleh bahwa peserta didik SD (diveger), SAs (assimilator), SK (konverger), dan SAk (akomodator) mampu memenuhi semua indikator kemampuan berpikir kritis matematis menurut Ennis yang digunakan pada penelitian ini yaitu elementary clarification, strategies \& tactis, advance clarification, dan inference. Namun, pada indikator elementary clarification terdapat perbedaan antara SD, SAs, SK, dan SAK dalam memfokuskan pertanyaan dari beberapa unsur yang diketahuinya. Kata Kunci: Berpikir Kritis, Gaya Belajar, Matematika.
\end{abstract}

\section{Students' Critical Thinking Ability in Solving Mathematical Problems Based on Learning Style}

\begin{abstract}
Critical thinking is a cognitive skill or strategy in setting goals. Each student has a different learning style. The purpose of this study is to describe the students' critical thinking skills in solving mathematical problems based on David Kolb's learning style. The approach in this study uses a qualitative approach. The selection of subjects in this study was based on purposive sampling, taking into account students who were able to take the test by fulfilling all the indicators of mathematical critical thinking ability to represent each type of learning style David Kolb. Data analysis techniques used include data reduction, data presentation, and data verification. The results obtained that elementary school students (diverge), SAs (assimilator), SK (convertor), and SAK (accommodator) can meet all the indicators of mathematical critical thinking skills according to Ennis used in this study, namely elementary clarification, strategies \& tactics, advance clarification, and inference. However, in the elementary clarification indicator, there are differences between SD, SAs, SK, and SA in focusing questions from some of the elements he knows.

Keywords: Critical Thinking, Learning Style, Mathematics.
\end{abstract}




\section{Pendahuluan}

Berpikir kritis seseorang merupakan suatu proses berpikir intelektual yang dengan sengaja menilai kualitas pemikirannya (Nurhikmayati \& Jatisunda, 2019), menggunakan pemikiran yang reflektif, independen, jernih, dan rasional. Proses tersebut merupakan bentuk berpikir kritis yang perlu dikembangkan dalam memecahkan masalah, merumuskan kesimpulan, mengumpulkan berbagai kemungkinan, dan membuat keputusan.

Ruseffendi (1991) menyatakan bahwa berpikir matematika berhubungan dengan ide, proses dan penalaran yang bermanfaat sebagai sarana berpikir logis, inovatif, dan sistematis. Dengan demikian melalui kegiatan matematika (Edo \& Samo, 2017) diharapkan memberikan sumbangan yang penting bagi peserta didik dalam mengembangkan nalar, berpikir logis, sistematis, kritis, cermat, dan bersikap objektif serta terbuka dalam menghadapi berbagai permasalahan (Damayanti \& Afriansyah, 2018).

DePorter dan Hernacki (2010) mengelompokan cara berpikir manusia ke dalam beberapa bagian, yaitu: berpikir vertical, berpikir lateral, berpikir kritis, berpikir analitis, berpikir strategis, berpikir tentang hasil, dan berpikir kreatif. Menurut keduanya berpikir kritis adalah melatih atau memasukkan penilaian atau evaluasi yang cermat, seperti menilai kelayakan, suatu gagasan atau produk.
Glaser (Fisher, 2009) mendefinisikan berpikir kritis sebagai suatu sikap mau berpikir secara mendalam tentang masalah-masalah dan hal-hal yang berada dalam jangkauan pengalaman seseorang; pengetahuan tentang metode-metode pemeriksaan dan penalaran yang logis (Afriansyah, 2015); dan semacam suatu keterampilan untuk menerapkan metodemetode tersebut. Berpikir kritis menuntut upaya keras untuk memeriksa setiap keyakinan atau pengetahuan asumtif berdasarkan bukti pendukungnya dan kesimpulan-kesimpulan lanjutan yang diakibatkannya (Mahardiningrum \& Ratu, 2018).

Fisher (2009) menyimpulkan definisi berpikir kritis yaitu "aktivitas terampil, yang bisa dilakukan dengan lebih baik atau sebaliknya, dan pemikiran kritis yang baik akan memenuhi beragam standar intelektual, seperti kejelasan, relevansi, kecukupan, koherensi, dan lain-lain". Hal ini sejalan dengan yang diungkapkan Syahbana (2012) mengenai kemampuan yang diperlukan dalam pembelajaran matematika yaitu "pembelajaran matematika dominan mengandalkan kemampuan daya pikir, sehingga perlu dibina kemampuan berpikir kritis peserta didik agar mampu mengatasi permasalahan pembelajaran matematika yang materinya cenderung bersifat abstrak".

Hendriana dan Soemarmo (2017) mengungkapkan beberapa indikator berpikir kritis matematik sebagai berikut: 
(a) memeriksa kebenaran argumen, pernyataan dan proses solusi; (b) menyusun pertanyaan disertai alasan; (c) mengidentifikasi data relevan dan tidak relevan suatu masalah matematika; (d) mengidentifikasi asumsi; dan (e) menyusun jawaban/ menyelesaikan masalah matematika disertai alasan.

Orang yang berpikir kritis diperlukan adanya suatu sikap keterbukaan terhadap ide-ide baru (Tarlina \& Afriansyah, 2016). Hal ini bukan sesuatu hal yang mudah akan tetapi harus dan tetap dilaksanakan dalam upaya mengembangkan kemampuan berpikir (Fisher, 2009).

Ennis (2009) mengungkapkan bahwa berpikir kritis matematik merupakan tingkatan berpikir tingkat tinggi, karena segala kemampuan diberdayakan, baik itu memahami, mengingat, membedakan menganalisis, memberi alasan, merefleksikan, menafsirkan, mencari hubungan, mengevaluasi, bahkan hingga membuat dugaan sementara.

Berdasarkan penelitian sebelumnya Anjani (2017) menjelaskan bahwa salah satu kemampuan peserta didik yang dikembangkan di sekolah adalah kemampuan berpikir kritis, untuk mengetahui kemampuan berpikir kritis peserta didik dapat dilihat berdasarkan indikator berpikir kritis. Hal lain yang perlu diperhatikan adalah karakteristik peserta didik, salah satunya gaya belajar peserta didik.

Dalam penelitian ini, peneliti akan melihat proses sistematis yang dilakukan peserta didik mulai dari merumuskan dan mengevaluasi pendapat mereka sendiri. Ketika peserta didik dihadapkan pada suatu masalah, kemampuan peserta didik bisa dianalisis dari keterampilan peserta didik menafsirkan masalah sehingga menjadi lebih mudah dipahami, kemudian mengumpulkan kemungkinan proses penyelesaiannya dan membuat keputusan untuk menyelesaikan masalah tersebut, hingga menggeneralisasikan masalah tersebut. Keterampilan-keterampilan tersebut bisa dianalisis dari 4 indikator kemampuan berpikir kritis yang dikemukakan oleh Ennis (1985) dan akan

Tabel 1.

Indikator Berpikir Kritis

\begin{tabular}{|c|c|c|}
\hline No & Indikator & Aktifitas \\
\hline 1 & $\begin{array}{l}\text { Elementary } \\
\text { clarification } \\
\text { (memberikan } \\
\text { penjelasan } \\
\text { sederhana) }\end{array}$ & $\begin{array}{l}\text { Mengidentifikasi } \\
\text { permasalahan } \\
\text { dengan } \\
\text { memfokuskan } \\
\text { pertanyaan dan } \\
\text { unsur yang terdapat } \\
\text { dalam masalah }\end{array}$ \\
\hline 2 & $\begin{array}{l}\text { Advance } \\
\text { clarification } \\
\text { (memberikan } \\
\text { penjelasan } \\
\text { lanjut) }\end{array}$ & $\begin{array}{l}\text { Mengidentifikasi } \\
\text { hubungan antara } \\
\text { konsep-konsep dalam } \\
\text { masalah dengan } \\
\text { membuat model } \\
\text { matematika dan } \\
\text { penjelasan } \\
\text { tepat }\end{array}$ \\
\hline 3 & $\begin{array}{l}\text { Strategies and } \\
\text { tactics } \\
\text { (menentukan } \\
\text { strategi dan } \\
\text { teknik) }\end{array}$ & $\begin{array}{l}\text { Menggunakan } \\
\text { strategi yang tepat } \\
\text { dalam menyelesaikan } \\
\text { masalah, serta } \\
\text { lengkap dan benar } \\
\text { dalam melakukan } \\
\text { perhitungan }\end{array}$ \\
\hline 4 & $\begin{array}{l}\text { Inference } \\
\text { (menyimpulka } \\
\text { n) }\end{array}$ & Membuat kesimpulan \\
\hline
\end{tabular}


digunakan dalam penelitian ini. Indikatorindikator tersebut disajikan dalam tabel 1.

Penelitian yang dilakukan oleh Jamilah (2018) menyimpulkan bahwa: peserta didik dengan Tipe Diverger, Converger, dan Accomodator masih tidak sempurna dalam menyelesaikan tahapan looking back. Peserta didik dengan tipe Diverger dan Assimilator masih belum bisa membuat kesimpulan akhir. Peserta didik dengan tipe Converger melakukan kesalahan pada perhitungan hasil akhir. Hanya peserta didik dengann tipe accomodator yang mampu melaksanakan tahapan looking back dengan benar.

Gaya belajar David Kolb merupakan salah satu model gaya belajar yang berdasarkan pada proses pengolahan informasi. David Kolb menegaskan bahwa orientasi peserta didik dalam proses belajar dipengaruhi empat kecenderungan, yaitu concrete experience (feeling), reflective observation (watching), abstract conceptualization (thinking), dan active experimentation (doing). Keempat kecenderungan belajar tersebut bila dikombinasikan akan membentuk empat tipe gaya belajar yaitu gaya belajar diverger, assimilator, konverger, dan akomodator (Ghufron \& Risnawati, 2014).

Menurut Ghufron \& Risnawati (2014), tentang dimensi atau tahap belajar pada gaya belajar David Kolb terdiri dari konverger, diverger, assimilator, dan akomodator. Berikut penjelasan dari setiap dimensi atau tahap belajar pada gaya belajar David Kolb.
Dimensi atau tahap belajar Konverger terdiri dari peserta didik yang dominan dalam Abstract Conceptualization (AC) dan Active Experimentation ( $A E)$. Kekuatan terbesar dimensi atau tahap belajar konverger adalah aplikasi praktis dari ideide. Peserta didik bisa memecahkan masalah dengan baik ketika ada solusi tunggal yang benar dari sebuah masalah dan peserta didik dapat berpusat pada masalah atau situasi tertentu. Pada penelitian ini peserta didik dengan dimensi atau tahap belajar konverger lebih suka berhubungan dengan benda-benda daripada peserta didik lainnya, jadi peserta didik dengan dimensi atau tahap belajar konverger ini lebih suka menyendiri.

Dimensi atau tahap belajar Diverger terdiri dari peserta didik yang dominan dalam Concrete Experience (CE) dan Reflective Observation (RO). Dimensi atau tahap belajar Diverger memiliki karakter yang berlawanan dengan konverger. Di sini kekuatan terbesar peserta didik terletak pada kemampuan berkreativitas dan berimajinasi. Mereka mampu melihat situasi nyata dari banyak sudut pandang dan memunculkan ide-ide. Pada penelitian ini peserta didik dengan dimensi atau tahap belajar diverger tertarik pada peserta didik lainnya, dalam hal ini bergaul dengan peserta didik lainnya dan cenderung berimajinasi serta emosional. Dalam pembelajaran, peserta didik dengan dimensi atau tahap belajar diverger lebih suka bekerja dalam kelompok, mendengarkan dengan pikiran terbuka 
dan menerima umpan balik yang dipersonalisasi.

Dimensi atau tahap belajar Assimilator terdiri dari peserta didik yang dominan dalam Abstract Conceptualization ( $A C$ ) dan Reflective Observation (RO). Peserta didik dengan dimensi atau tahap belajar Assimilator mampu memahami teori. Peserta didik sudah lebih baik dalam penalaran induktif dan menyatukan ideide yang bervariasi dan pengamatan ke dalam kesatuan yang utuh. Seperti dimensi atau belajar konverger, peserta didik kurang tertarik pada peserta didik lainnya dan lebih memperhatikan konsepkonsep yang abstrak, kurang memperhatikan praktik dari kegunaan teori-teori yang ada.

Dimensi atau tahap belajar Akomodator. merupakan bentuk yang berlawanan dengan assimilator. Peserta didik sudah lebih baik dalam melaksanakan rencana dan percobaan dan melibatkan diri mereka pada pengalaman yang baru. Dalam hal ini peserta didik berani mengambil risiko dan unggul dalam melewati situasi-situasi yang membutuhkan keputusan dan adaptasi yang cepat. Peserta didik lebih berani menyelesaikan masalah dengan sebuah percobaan trial and eror, dan sangat bergantung pada orang lain untuk memperoleh informasi. Akomodator senang dengan orang-orang tetapi terlihat tidak sabar dan ambisius (Kolb \& Kolb, 2005).
Berdasarkan uraian sebelumnya, tujuan dalam penelitian ini adalah untuk mendeskripsikan kemampuan berpikir kritis peserta didik yang meliputi elementary clarification, advance clarification, strategies and tactics, dan inference dalam memecahkan masalah matematik berdasarkan gaya belajar David Kolb yang terdiri dari dimensi atau tahap belajar diverger, assimilator, konverger, akomodator.

\section{Metode}

Penelitian ini menggunakan metode penelitian kualitatif. Moleong (2014) mengungkapkan "Penelitian kualitatif adalah penelitian yang bermaksud untuk memahami fenomena tentang apa yang dialami oleh subjek penelitian misalnya perilaku, persepsi, motivasi, tindakan dll. Secara holistik dan bahasa, pada suatu konteks khusus yang alamiah dan dengan memanfaatkan berbagai metode alamiah" (Moleong, 2014).

Teknik pengambilan subjek pada penelitian ini menggunakan kualitatif eksplorasi terhadap siswa kelas VIII pada saat mengerjakan soal tes kemampuan berpikir kritis matematis ditinjau dari gaya belajar David Kolb. Sedangkan teknik pengambilan datanya dengan menggunakan Thinking Aloud Method (TA). Menurut Markopoulos dan Bekker, Thinking Aloud Method (TA) merupakan metode yang paling langsung memunculkan verbalisasi pemikiran anak ketika diberikan tugas. 
Penelitian ini dilaksanakan di SMPN 2 Tasikmalaya yang beralamat di Jln. Alunalun Kabupaten No.1 Kelurahan Empangsari Kecamatan Tawang Kota Tasikmalaya. Subjek penelitian diambil dengan cara purposive sampling. Subjek yang diambil dalam penelitian ini adalah subjek yang mengerjakan semua indikator kemampuan berpikir kritis pada masingmasing gaya berpikir dan dapat memberikan informasi yang lebih dalam pada saat wawancara terkait dengan kemampuan berpikir kritisnya.

Teknik pengumpulan data pada penelitian ini dengan menggunakan angket gaya belajar, tes kemampuan berpikir kritis, dan wawancara tidak terstruktur. Angket yang digunakan merupakan angket penggolongan gaya belajar KLSI (Kolb Learning Style Inventory) menurut Kolb. Hasil dari pengisian angket gaya belajar Kolb kemudian di klasifikasikan berdasarkan dimensi atau tahap belajar konverger, diverger, akomodator, dan asimilator. Tes kemampuan berpikir kritis yang digunakan dalam penelitian ini berupa soal tes uraian sebanyak 5 buah soal yang memuat indikator kemampuan berpikir kritis. Tujuan dari pelaksanaan tes ini adalah untuk mengetahui kemampuan berpikir kritis peserta didik dalam memecahkan masalah matematik. Wawancara dilakukan untuk untuk memperoleh informasi lebih detail atau mendalam tentang kemampuan berpikir kritis matematis peserta didik dalam memecahkan masalah matematik.

Teknik analisis data dalam penelitian ini menggunakan teknik analisis data yang dikemukakan oleh Miles dan Huberman (Sugiyono, 2015) yaitu data reduction (reduksi data), data display (penyajian data), dan conclusion (verification). "Mereduksi data berati merangkum, memilih hal-hal yang pokok, memfokuskan pada hal-hal penting, dicari tema dan polanya". Berikut tahapan reduksi data dalam penelitian ini yaitu: (1) Hasil angket gaya belajar peserta didik diklasifikasikan berdasarkan gaya belajar (diverger, assimalator, konvergen, akomodator); (2) Hasil tes peserta didik yang menjadi subjek penelitian merupakan data yang masih mentah. Data tersebut dianalisis kemampuan berpikir kritis matematisnya, lalu untuk memperoleh data yang lebih akurat akan dibuat catatan dari hasil tes yang sudah dikerjakan sebagai bahan untuk wawancara; dan (3) Hasil wawancara dengan subjek penelitian disusun menjadi bahasa yang baik sehingga menjadi data yang siap disajikan.

Penyajian data dalam penelitian ini adalah dengan teks yang bersifat naratif. $\mathrm{Hal}$ ini sejalan dengan pendapat Miles dan Huberman yaitu "Yang paling sering digunakan untuk menyajikan data dalam penelitian kualitatif adalah dengan teks yang bersifat naratif" (Sugiyono, 2015). Penyajian data dalam penelitian ini adalah menyajikan hasil tes kemampuan berpikir kritis matematis peserta didik, hasil angket 
gaya belajar peserta didik, dan hasil wawancara subjek penelitian tentang kemampuan berpikir kritis matematis dalam memecahkan masalah matematik.

Menurut Miles dan Huberman (Sugiyono, 2015), "Langkah terakhir pada analisis data kualitatif adalah penarikan kesimpulan dan verifikasi". Dalam hal ini, peneliti menarik kesimpulan berdasarkan hasil tes kemampuan berpikir kritis dalam memecahkan masalah matematis, hasil angket gaya belajar, dan wawancara untuk mengetahui bagaimana deskripsi kemampuan berpikir kritis matematis dalam memecahkan masalah matematis ditinjau dari gaya belajar.

\section{Hasil dan Pembahasan}

Tes kemampuan berpikir kritis matematis diberikan kepada 32 subjek secara perorangan. Bersamaan dengan itu, peneliti mengamati gaya belajarnya. Adapun wawancara dilakukan untuk penggalian lebih dalam untuk mengetahui informasi dari subjek tersebut. Beberapa instrumen yang diperlukan meliputi angket gaya belajar yang sebelumnya divalidasi oleh dua orang psikolog, soal tes kemampuan berpikir kritis yang sebelumnya divalidasi oleh ahli yaitu dosen di jurusan pendidikan matematika, dan pedoman wawancara.

Angket yang dikembangkan dalam penelitian ini adalah angket penggolongan gaya belajar KLSI (Kolb Learning Style Inventory), sehingga melalui angket ini peneliti dapat mengklasifikasikan dimensi atau tahap belajar konverger, diverger, akomodator, dan assimilator. Tes kemampuan berpikir kritis yang digunakan dalam penelitian ini berupa soal tes berbentuk uraian sebanyak 5 buah soal yang memuat indikator kemampuan berpikir kritis, yaitu elementary clarification, basic support, inference, advanced clarification, strategies and tactics. Wawancara ini dilakukan untuk memperoleh informasi lebih dalam atau detail tentang kemampuan berpikir kritis matematis peserta didik dalam memecahkan masalah matematis.

Berdasarkan hasil pengamatan, peneliti mengambil sumber data sebanyak 4 peserta didik, yaitu S-6 dengan dimensi atau tahap belajar konverger (SK), S-23 engan dimensi atau tahap belajar akomodator (SAK), S-30 engan dimensi atau tahap belajar diverger (SD), dan S-32 engan dimensi atau tahap belajar assimilator (SAs). Berikut deskripsi kemampuan berpikir kritis peserta didik dalam memecahkan masalah matematik:

Subjek (S-6) dengan dimensi atau tahap belajar konverger (SK), pada indikator elementary Clarification (memberikan penjelasan sederhana), yang meliputi mampu mengidentifikasi permasalahan dengan memfokuskan pertanyaan dan unsur yang terdapat dalam masalah, SK dapat memahami dan mengidentifikasi masalah dengan menuliskan unsur-unsur yang diketahui dan mampu membuat 4 buah pertanyaan pada saat mengerjakan soal tes dan menambahkan 1 buah 
pertanyaan lagi pada saat wawancara (lihat gambar 1). Hal ini sejalan dengan yang dikatakan oleh Gufron \& Risnawita (2014) mengatakan bahwa individu dengan tipe konverger biasanya mereka punya kemampuan yang baik dalam pemecahan masalah dan pengambilan keputusan.

Pada indikator strategi and tactis (menentukkan strategi dan teknik), meliputi menggunakan strategi yang tepat dalam menyelesaikan masalah, serta lengkap dan benar dalam melakukan perhitungan, SK mampu menggunakan strategi yang tepat dalam menjawab pertanyaan yang dibuatnya dengan tepat dan penghitungan yang benar. Dalam menjawab pertanyaan SK menjawab pertanyaan dengan runtut dan sistematis. Hal ini sejalan dengan yang dikatakan oleh Gufron \& Risnawita (2014) bahwa individu yang berada pada kuadran abstract conceptualization dalam memecahkan sebuah masalah, individu akan bekerja secara vertikal, runtut, sistematis, dan step-by-step.

Pada indikator advance clarification (memberikan penjelasan lanjut), meliputi mengidentifikasi hubungan antara konsepkonsep dalam masalah dengan membuat model matematika dan penjelasan yang tepat dari pertanyaan yang dibuatnya, SK mampu memberikan penjelasan lanjut dari pertanyaan yang dibuatnya dan membuat model matematika yang benar.

Pada indikator inference (menyimpulkan) yaitu mampu membuat kesimpulan dengan tepat, SK dapat membuat kesimpulan dengan lengkap dari semua pertanyaan yang telah dibuatnya. SK mampu membuat penjelasan lanjut terkait dengan jawaban sebelumya dan SK mampu menggunakan model matematika dan penjelasan yang tepat.

Subjek (S-23) dengan dimensi atau tahap belajar akomodator (SAk), pada indikator elementary clarification (memberikan penjelasan sederhana), meliputi mampu mengidentifikasi permasalahan dengan memfokuskan pertanyaan dan unsur yang terdapat dalam masalah, SAk dapat memahami dan mengidentifikasi masalah dengan menuliskan unsur-unsur yang diketahui dan mampu membuat 3 buah pertanyaan dan menambahkan 1 pertanyaan lagi saat wawancara (lihat gambar 2). SAk mampu mengilustrasikan unsur yang diketahuinya ke dalam bentuk gambar bangun ruang balok. Hal ini sesuai dengan yang dikatakan oleh Gufron \& Risnawita (2014) bahwa individu degan tipe akomodator suka membuat rencana dan melibatkan dirinya dalam berbagai pengalaman baru dan menantang.

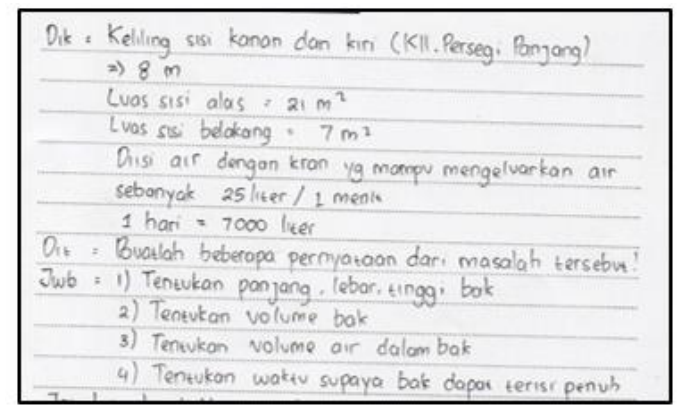

Gambar 1. Jawaban SK pada Indikator Elementary Clarification. 
Pada indikator strategy and tactis (menentukkan strategi dan teknik), meliputi menggunakan strategi yang tepat dalam menyelesaikan masalah, serta lengkap dan benar dalam melakukan perhitungan, SAK mampu menjawab pertanyaan yang dibuatnya dengan menggunakan strategi yang tepat, lengkap dan benar.

Pada indikator advance clarification (memberikan penjelasan lanjut), meliputi mengidentifikasi hubungan antara konsepkonsep dalam masalah dengan membuat model matematika dan penjelasan yang tepat, SAk mampu mengindentifikasi hubungan antara konsep-konsep dengan unsur-unsur yang diketahuinya dan SAk mampu membuat penjelasan lebih lanjut terkait dengan jawaban sebelumya dan SAk mampu menggunakan model matematika dengan penjelasan yang tepat.

Pada indikator inference (menyimpulkan) yaitu mampu membuat kesimpulan dengan tepat, SAk dapat membuat kesimpulan dengan lengkap dari semua pertanyaan yang telah dibuatnya.

Subjek (S-30) dengan dimensi atau

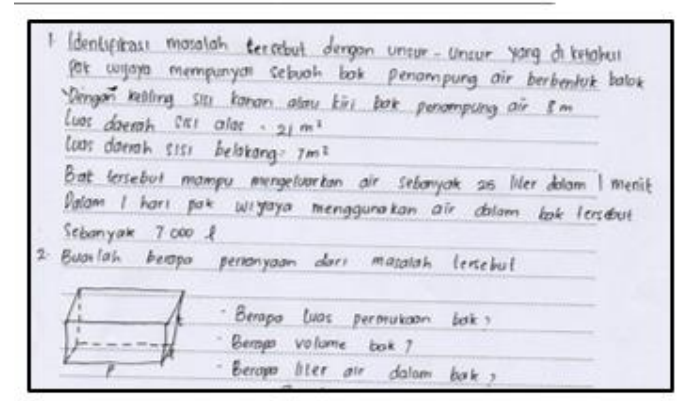

Gambar 2. Jawaban SAk pada Indikator Elementary Clarification. tahap belajar diverger (SD), pada indikator elementary clarification (memberikan penjelasan sederhana), meliputi mampu mengidentifikasi permasalahan dengan memfokuskan pertanyaan dan unsur yang terdapat dalam masalah, SD dapat memahami dan mengidentifikasi masalah dengan menuliskan unsur-unsur yang diketahui dan mampu membuat 2 buah pertanyaan (lihat gambar 3). SD dalam mengerjakan tes kemampuan berpikir kritis terlihat lama, hal ini sejalan dengan yang dikatakan oleh Gufron \& Risnawita (2014) bahwa individu cepat bosan jika persoalan membutuhkan waktu yang lama untuk dapat dipahami, dipecahkan, atau diselesaikan.

Pada indikator strategy and tactis (menentukkan strategi dan teknik), meliputi menggunakan strategi yang tepat dalam menyelesaikan masalah, serta lengkap dan benar dalam melakukan perhitungan, SD mampu menggunakan startegi yang tepat dalam menyelesaikan pertanyaan yang dibuatnya, serta lengkap dan benar dalam melakukan perhitungan. Hal ini sesuai dengan yang dikatakan oleh Gufron \& Risnawita (2014) bahwa individu yang berada pada kuadran reflective observation melihat masalah dari berbagai perspektif.

Pada indikator advance clarification (memberikan penjelasan lanjut), meliputi mengidentifikasi hubungan antara konsepkonsep dalam masalah dengan membuat model matematika dan penjelasan yang tepat, SD mampu mengidentifikasi 
hubungan antara konsep-konsep dalam masalah dengan membuat model matematika dengan penjelasan yang tepat. SD terlihat lama dalam memahami unsur-unsur yang diketahuinya untuk memfokuskan pertanyaanya. Hal ini sesuai dengan yang dikatakan oleh Gufron \& Risnawita (2014) bahwa individu cepat bosan jika persoalan membutuhkan waktu yang lama untuk dapat dipahami, dipecahkan, atau diselesaikan.

Pada indikator inference (menyimpulkan) yaitu mampu membuat kesimpulan dengan tepat, SD dapat membuat kesimpulan dengan lengkap dari semua pertanyaan yang telah dibuatnya. Dalam membuat kesimpulan SD kurang teliti dalam menuliskannya. Akan tetapi pada saat diwawancara SD bisa melengkapi kesimpulannya secara lisan kepada peneliti. Hal ini sejalan dengan pendapat dari Gufron \& Risnawita (2014) bahwa individu dengan gaya belajar diverger tidak takut untuk mencoba.

Subjek (S-32) dengan dimensi atau tahap belajar assimilator (SAs), pada indikator elementary clarification (memberikan penjelasan sederhana), meliputi mampu mengidentifikasi

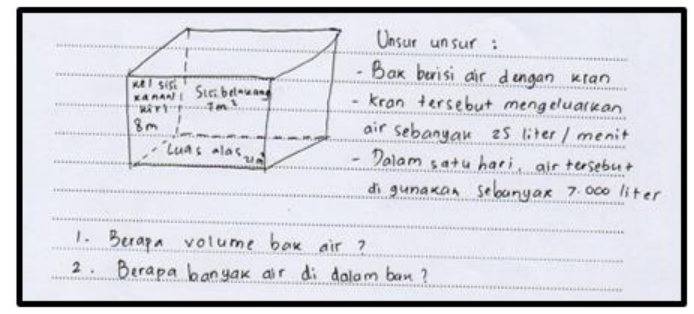

Gambar 3. Jawaban SD pada Indikator Elementary Clarification permasalahan dengan memfokuskan pertanyaan dan unsur yang terdapat dalam masalah, SAs Mampu mengidentifikasi permasalahan dengan memfokuskan 3 pertanyaan dari semua unsur yang diketahuinya (lihat gambar 4). Hal ini sesuai dengan yang dikatakan oleh Gufron \& Risnawita (2014) bahwa individu dengan tipe assimilator memiliki kelebihan dalam memahami berbagai sajian informasi yang dikumpulkan dari berbagai sumber.

Pada indikator strategy and tactis (menentukkan strategi dan teknik), meliputi menggunakan strategi yang tepat dalam menyelesaikan masalah, serta lengkap dan benar dalam melakukan perhitungan, SAs mampu menggunakan startegi yang tepat dalam menyelesaikan pertanyaan yang dibuatnya, serta lengkap dan benar dalam melakukan perhitungan. SAs cenderung lama dalam menjawab pertanyaan. Hal ini sejalan dengan Gufron \& Risnawita (2014) bahwa individu dengan

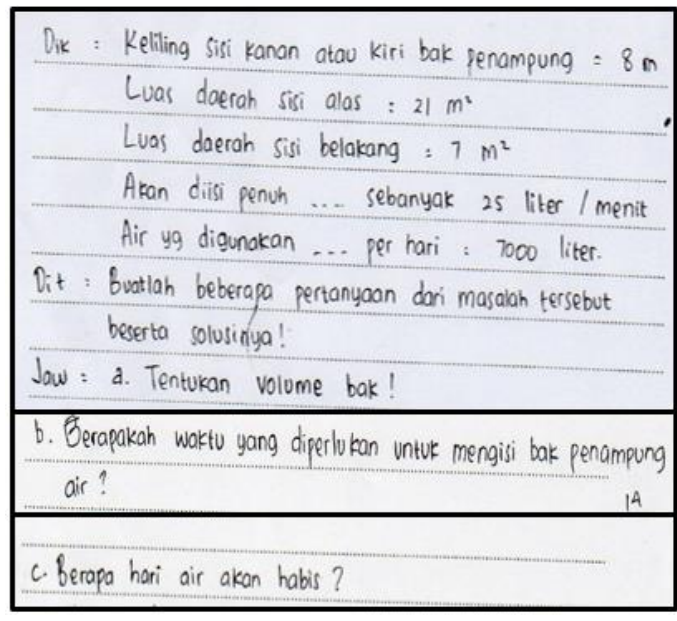

Gambar 4. Jawaban SAs pada Indikator Elementary Clarification. 
tipe asimilator melihat masalah dari berbagai perspektif, mengumpulkan sebanyak-sebanyaknya data yang berhubungan dengan permasalahan dari berbagai sumber, sehingga terkadang terlihat suka menunda-nunda menyelesaikan masalah

Pada indikator advance clarification (memberikan penjelasan lanjut), meliputi mengidentifikasi hubungan antara konsepkonsep dalam masalah dengan membuat model matematika dan penjelasan yang tepat, SAs mampu mengidentifikasi hubungan antara konsep-konsep dalam masalah dengan membuat model matematika dengan penjelasan yang tepat.

Pada indikator inference (menyimpulkan) yaitu mampu membuat kesimpulan dengan tepat, SD dapat membuat kesimpulan dengan lengkap dari semua pertanyaan yang telah dibuatnya.

\section{Penutup}

Peserta didik sudah mampu memecahkan masalah matematik pada indikator kemampuan berpikir kritis yaitu mampu memberikan penjelasan sederhana, menentukan strategi dan teknik, memberikan penjelasan lanjut, dan menyimpulkan; Peserta didik mampu membuat 4 buah pertanyaan; Peserta didik mampu membuat 2 buah pertanyaan; dan peserta didik mampu membuat 3 pertanyaan dari semua unsur yang diketahuinya.

\section{Daftar Pustaka}

Afriansyah, E. A. (2015). Students' Misconception in Decimal Numbers. International Seminar on Teacher Education 1st ISTE UIN SUska Riau.

Damayanti, R., \& Afriansyah, E. A. (2018). Perbandingan Kemampuan Representasi Matematis Siswa antara Contextual Teaching and Learning dan Problem Based Learning. JIPM (Jurnal Ilmiah Pendidikan Matematika), 7(1), 30-39.

DePorter \& Hernacki. (2010). Quantum Learning. Bandung: Kaifa.

Edo, S. I., \& Samo, D. D. (2017). Lintasan Pembelajaran Pecahan Menggunakan Matematika Realistik Konteks Permainan Tradisional Siki Doka. Mosharafa: Jurnal Pendidikan Matematika, 6(3), 311-322.

Ennis, R. H. (1985). A logical basis for measuring critical thinking skills. Educational Leadership, 43(2), 44-48. Retrieved from https://pdfs.semanticscholar.org/80a 7/c7d4a98987590751df4b1bd9adf74 $7 f d 7 a a a . p d f$

Ennis, R. H. (2009). Critical thinking assessment. Theory Into Practice, 32(3), 179-186. DOI: 10.1080/00405849309543594.

Fisher, A. (2009). Berpikir Kritis Sebuah Pengantar. Jakarta: Erlangga.

Ghufron, M. N. \& Risnawita, R. (2014). Gaya belajar: Kajian Teoretik. Yogyakarta, Indonesia: Pustaka Pelajar. 
Hendriana, H. \& Soemarmo, U. (2017). Penilaian Pembelajaran Matematika. Bandung: PT Refika Aditama.

Jamilah, I. (2018). Analisis Kemampuan Pemecahan Masalah Matematis ditinjau dari Gaya Belajar menurut David Kolb. Skripsi. Program Studi Pendidikan Matematika Universitas Siliwangi.

Mahardiningrum, A. S., \& Ratu, N. (2018). Profil Pemecahan Masalah Matematika Siswa SMP Pangudi Luhur Salatiga Ditinjau dari Berpikir Kritis. Mosharafa: Jurnal Pendidikan Matematika, 7(1), 75-84.

Nurhikmayati, I., \& Jatisunda, M. G. (2019). Pengembangan Bahan Ajar Matematika Berbasis Scientific yang Berorientasi pada Kemampuan Berpikir Kritis Matematis Siswa. Mosharafa: Jurnal Pendidikan Matematika, 8(1), 49-60.

Kolb, A. Y \& Kolb, D. A. (2005). Learning styles and learning spaces: Enhancing experiential learning in higher education. Academy of Management, 4(2), 193-212.

Moleong, L. J. (2014). Metodologi penelitian kualitatif. Bandung, Indonesia: PT Remaja Rosdakarya

Ruseffendi, E. T. (1991). Pengantar Kepada Membantu Guru Mengembangkan Kompetensinya dalam pembelajaran Matematika Untuk Meningkatkan CBSA. Bandung: Tarsito.
Sugiyono. (2015). Metode Penelitian Kuantitatif Kualitatif dan R\&D. Bandung, Indonesia: Alfabeta.

Syahbana, A. (2012). Peningkatan Kemampuan Berpikir Kritis Matematika Siswa SMP melalui Pendekatan Contextual Teaching and Learning. Jurnal Edumatica, 2(1), 4557.

Tarlina, W. H., \& Afriansyah, E. A. (2016). Kemampuan Berpikir Kreatif Siswa Melalui Creative Problem Solving. Eduma: Mathematics Education Learning and Teaching, 5(2), 42-51.

\section{Riwayat Hidup PenUlis}

\section{Vepi Apiati, M.Pd.}

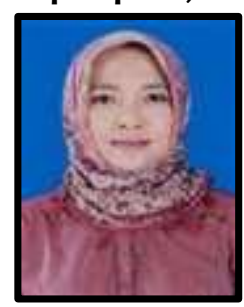

Lahir di Ciamis, 27 April 1975. Staf pengajar di Jurusan Pendidikan Matematika FKIP Universitas Siliwangi. Studi S1 Pendidikan Matematika FKIP Universitas Siliwangi, Tasikmalaya, lulus tahun 1998; Studi S2 Pendidikan Matematika Universitas Pendidikan Indonesia (UPI), Bandung, lulus tahun 2012; Menulis buku Aplikasi Matematika dalam Bidang Ekonomi.

\section{Redi Hermanto, M.Pd.}

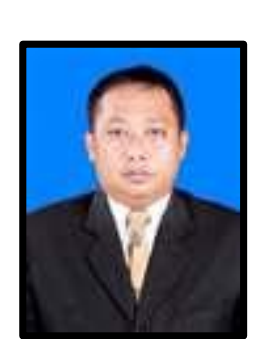

Lahir di Sukabumi, 10 September 1981. Staf pengajar di Jurusan Pendidikan Matematika FKIP Universitas Siliwangi. Studi S1 Pendidikan Matematika FKIP Universitas Siliwangi, Tasikmalaya, lulus tahun 2003; Studi S2 Pendidikan Matematika Universitas Pendidikan Indonesia (UPI), Bandung, lulus tahun 2011. Menulis buku Aplikasi Microsoft Office Excel 2016 dalam Pengolahan Data Statistik; Pemodelan Matematika dan Aplikasi Teori Graf dalam Kehidupan Sehari-hari. 